\title{
GMR
}

\section{Genetic structure of Pilosocereus gounellei (Cactaceae) as revealed by AFLP marker to guide proposals for improvement and restoration of degraded areas in Caatinga biome}

\author{
E.R. Monteiro ${ }^{1}$, D.K. Strioto ${ }^{1}$, A.C.S. Meirelles ${ }^{2}$, C.A. Mangolin ${ }^{3}$ and \\ M.F.P.S. Machado ${ }^{3}$ \\ ${ }^{1}$ Programa de Pós-Graduação em Genética e Melhoramento, \\ Universidade Estadual de Maringá, Maringá, PR, Brasil \\ 2Programa de Pós-Graduação Agronomia, \\ Universidade Estadual de Maringá, Maringá, PR, Brasil \\ ${ }^{3}$ Departamento de Biotecnologia, Genética e Biologia Celular, \\ Universidade Estadual de Maringá, Maringá, PR, Brasil \\ Corresponding author: M.F.P.S. Machado \\ E-mail: mfpsmachado@uem.br
}

Genet. Mol. Res. 14 (4): 16966-16974 (2015)

Received May 25, 2015

Accepted July 22, 2015

Published December 15, 2015

DOI http://dx.doi.org/10.4238/2015.December.15.2

\begin{abstract}
Amplified fragment length polymorphism (AFLP) analysis was used to evaluate DNA polymorphism in Pilosocereus gounellei with the aim of differentiating samples grown in different Brazilian semiarid regions. Seven primer pairs were used to amplify 703 AFLP markers, of which $700(99.21 \%)$ markers were polymorphic. The percentage of polymorphic markers ranged from $95.3 \%$ for the primer combination E-AAG/M-CTT to $100 \%$ for E-ACC/M-CAT, E-ACC/M-CAA, E-AGC/M-CAG, E-ACT/M-CTA, and E-AGG/M-CTG. The largest number of informative markers (126) was detected using the primer combination E-AAC/M-CTA. Polymorphism of the amplified DNA fragments ranged from $72.55 \%$ (in sample from Piaui State) to $82.79 \%$ (in samples from Rio Grande Norte State), with an
\end{abstract}


average of $75.39 \%$. Despite the high genetic diversity of AFLP markers in xiquexique, analysis using the STRUCTURE software identified relatively homogeneous clusters of xiquexique from the same location, indicating a differentiation at the molecular level, among the plant samples from different regions of the Caatinga biome. The AFLP methodology identified genetically homogeneous and contrasting plants, as well as plants from different regions with common DNA markers. Seeds from such plants can be used for further propagation of plants for establishment of biodiversity conservation units and restoration of degraded areas of the Caatinga biome.

Key words: Xiquexique; Cactus; Semiarid region; Genetic diversity; AFLP

\section{INTRODUCTION}

In the semiarid region of Northeastern Brazil, several cacti are important for the regional fauna and flora (Rocha and Agra, 2002). Fruits of the cacti also constitute a food resource for humans (Albuquerque and Andrade, 2002; Almeida et al., 2007). Cactus, popularly known as xiquexique, belongs to the species Pilosocereus gounellei (Web.) Byl. \& Rowl. (Byles and Rowley, 1957 ) and is found in sandy-stony soils and rock outcrops (Rocha and Agra, 2002) as well as in degraded soil areas and regions with irregular rainfall distribution. Xiquexique can be considered an option to repopulate areas where it is impossible to grow traditional crops (Cavalcanti and Resende, 2007). Its distribution mainly covers the states of Ceará, Rio Grande do Norte, and Bahia (Silva et al., 2005), which are part of the Caatinga biome.

$P$. gounellei has been used as forage for ruminants such as dairy cattle (Silva et al., 2005), ovines (Silva et al., 2010a), caprines (Cavalcanti and Resende, 2007; Silva et al., 2011), and calves (Silva et al., 2010b). Xiquexique fruits are consumed fresh by humans (Barbosa et al., 2007; Lucena et al., 2012) and their pulp is used to prepare cookies, pies, and pastries (Almeida et al., 2007). Xiquexique plants constitute a wild natural resource with an important contribution to the livelihood of local people in semiarid region of the Brazilian Northeast.

Owing to several uses of the plants endemic to the semiarid regions, utilization of Caatinga resources in a sustainable way is a challenge. In addition to biodiversity conservation, restoration of degraded areas has been a growing concern and has encouraged studies for the genetic characterization of these resources. Such characterization is essential for the successful conservation of plant resources, ensuring their sustainable use (Arif et al., 2010). For this purpose, molecular tools developed in recent years, such as amplified fragment length polymorphism (AFLP) markers provide an efficient means to evaluate known and unknown plant taxa. According to Vos et al. (1995), AFLP technique is based on the detection of genomic restriction fragments via Polymerase Chain Reaction (PCR) and has proven to be an extremely effective tool to distinguish between closely related genotypes. AFLP analysis has great potential as a technique for examining plant genetic diversity because a large number of polymorphisms can be detected with no prior sequence information and many markers can be analyzed in short time. Compared to other molecular methods, this technique requires relatively less DNA and has great discriminatory power and reproducibility (Geornaras et al., 1999). This technique has been used for the study of some cacti, such as the species of genus Opuntia (Labra et al., 2003; Nilsen et al., 2005; GarcíaZambrano et al., 2009), Gymnocalycium (Repka and Mrácek, 2012), and Cereus (Faria-Tavares et al., 2013). 
Since there is no information available in literature on the genetic parameters of $P$. gounellei, the present study was aimed to evaluate the genetic diversity among samples obtained from the states of Bahia, Piauí, and Rio Grande do Norte, using the AFLP technique. The application of this technique revealed the genetic structure of these samples that could be useful in guiding proposals for i) the improvement of this species, ii) the use of $P$. gounellei for restoring degraded areas, and iii) the establishment of biodiversity conservation units. The indiscriminate use of plants as forage for animals and for human consumption, and the predominantly vegetative form of propagation for producing seedlings, can reduce the local genetic diversity leading to genetic divergence among samples of $P$. gounellei collected from different states of the Caatinga biome.

\section{MATERIAL AND METHODS}

\section{Xiquexique samples}

Seeds collected from 21 xiquexique samples from the Northeast Brazilian states of Piauí (PI), Rio Grande do Norte (RN), and Bahia (BA) were germinated under aseptic conditions to form plantlets. Xiquexique plants used as the source of the seeds were grown in home gardens in the cities of Teresina, Campo Maior, and Picos in PI, Oliveira dos brejinhos and Queimada Nova in BA, and in an experimental field in Cruzeta, RN (Figure 1; Table 1). The distance separating the seed-donor plants grown in home gardens was 1000-7000 m (within each city), while the distance between the plants grown in the experimental field of Cruzeta was 5-30 m. Seeds were germinated on KC medium (Knudson, 1946) according to the protocol described by Oliveira et al. (1995) and maintained in a chamber acclimatized at $30^{\circ} \mathrm{C}$ with a photoperiod of $12 \mathrm{~h}$. Five-to-twelve-month-old plantlets were used for DNA extraction.

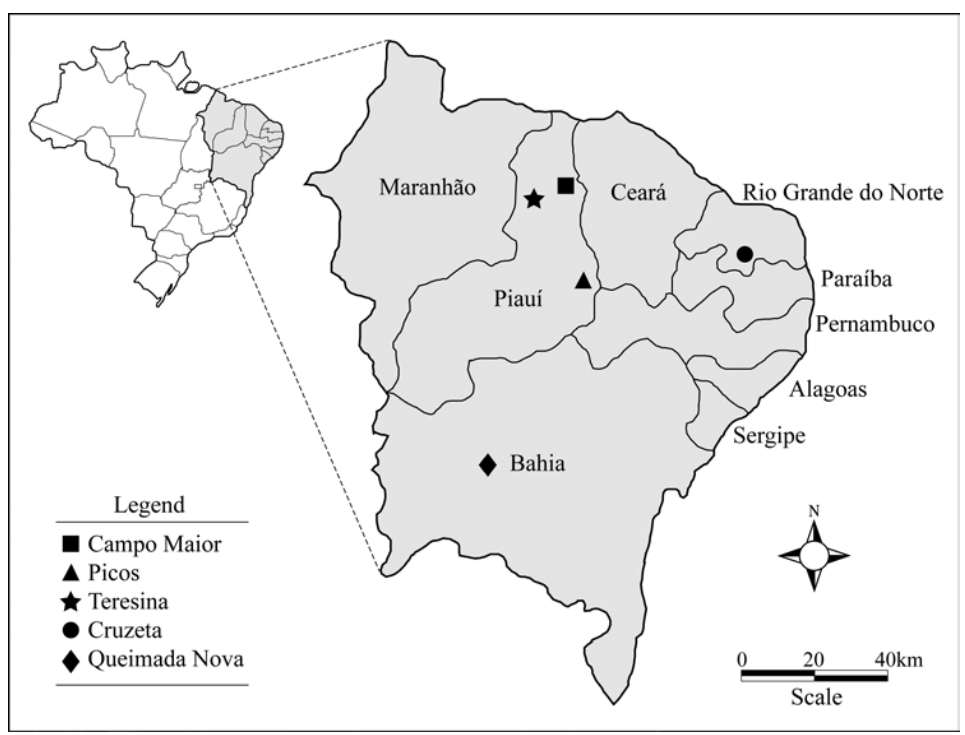

Figure 1. Origin of the Pilosocereus gounellei plants whose seeds were germinated to form plantlets representative of the Caatinga biome. Fruit was collected from the plants growing in areas of natural occurrence, gardens, and experimental fields in the cities of the Brazilian states Piauí (PI), Rio Grande do Norte (RN), and Bahia (BA). 
Table 1. Collection sites and number of samples of Pilosocereus gounellei.

\begin{tabular}{|c|c|c|}
\hline City (State) & Sample & Geographic coordinate \\
\hline \multirow[t]{3}{*}{ Teresina (PI) } & Te-1 & $5^{\circ} 5^{\prime} 20^{\prime \prime S} / 42^{\circ} 48^{\prime} 07^{\prime \prime W} / 72 \mathrm{~m}$ \\
\hline & Te-2 & \\
\hline & Te-3 & \\
\hline Picos (PI) & Pi-4 & 74'37"S/41ํ28'1"W/206 m \\
\hline \multirow{2}{*}{ Campo Maior (PI) } & CM-5 & $4^{\circ} 49^{\prime} 40^{\prime S} \mathrm{~S} / 42^{\circ} 10^{\prime} 7 " \mathrm{~W} / 125 \mathrm{~m}$ \\
\hline & CM-6 & \\
\hline \multirow[t]{5}{*}{ Oliveira dos brejinhos, in Queimada Nova (BA) } & QN-7 & $10^{\circ} 56^{\prime} 9 " \mathrm{~S} / 41^{\circ} 56^{\prime} 51 " \mathrm{~W} / 550 \mathrm{~m}$ \\
\hline & QN-8 & \\
\hline & QN-9 & \\
\hline & QN-10 & \\
\hline & QN-11 & \\
\hline \multirow[t]{10}{*}{ Cruzeta (RN) } & $\mathrm{Cz}-12$ & $6^{\circ} 26^{\prime} \mathrm{S} / 36^{\circ} 35^{\prime} \mathrm{W} / 230 \mathrm{~m}$ \\
\hline & $\mathrm{Cz}-13$ & \\
\hline & $C z-14$ & \\
\hline & $C z-15$ & \\
\hline & $C z-16$ & \\
\hline & $\mathrm{Cz}-17$ & \\
\hline & Cz-18 & \\
\hline & Cz-19 & \\
\hline & $\mathrm{Cz}-20$ & \\
\hline & $\mathrm{Cz}-21$ & \\
\hline
\end{tabular}

\section{DNA isolation and AFLP assay}

DNA was isolated according to the protocol originally described by Aljanabi et al. (1999), incorporating minor modifications proposed by Resende et al. (2010). These modifications included the use of $400 \mu \mathrm{L} 7.5 \mathrm{M}$ ammonium acetate after centrifugation with chloroform/isoamyl alcohol (24:1), and the use of $3 \mathrm{M} \mathrm{NaCl}$ and $3 \%(\mathrm{w} / \mathrm{v})$ CTAB. DNA concentration was estimated using a UV-visible spectrophotometer Picodrop ${ }^{\circledR}$.

AFLP amplification was performed using AFLP ${ }^{\circledR}$ Analysis System I and AFLP ${ }^{\circledR}$ Starter Primer Kit (Invitrogen). The sequence of the adaptors and pre-selective amplification primers are given in Table 2. Genomic DNA (300 ng) was digested with EcoRI and Msel ( $3 \mathrm{U}$ each) in a $25 \mu \mathrm{L}$ standard reaction mix for $3 \mathrm{~h}$ at $37^{\circ} \mathrm{C}$ in a Techne TC-512 thermocycler. Thereafter, the restriction endonucleases were heat inactivated at $70^{\circ} \mathrm{C}$ for $15 \mathrm{~min}$ followed by ligation of the DNA fragments to $E c o R I$ and $M s e l$ adapters in a ligation reaction containing $24 \mu \mathrm{L}$ adaptor solution [EcoRI/Msel adapters, $0.4 \mathrm{mM}$ ATP, $10 \mathrm{mM}$ Tris- $\mathrm{HCl}(\mathrm{pH} 7.5), 10 \mathrm{mM}$ Mg-acetate, $50 \mathrm{mM} \mathrm{K}$-acetate] and $1 \mu \mathrm{L}$ T4 DNA ligase $(1 \mathrm{U} / \mathrm{mL})$. The ligation was carried out at $20^{\circ} \mathrm{C}$ for $2 \mathrm{~h} 30 \mathrm{~min}$ in a Techne TC-512 thermocycler generating the template DNA for amplification. The fragments were pre-amplified according to the method of Labra et al. (2003). The pre-amplification reactions were performed with $2.5 \mu \mathrm{L}$ DNA containing the adaptors (obtained after the ligation), $20 \mu \mathrm{L}$ primer mixture for the pre-amplification, $2.5 \mu \mathrm{L}$ 10X PCR buffer with $\mathrm{Mg}^{2+}$ and $0.5 \mu \mathrm{L}$ Platinum Taq DNA polymerase (5 U/ $\mu \mathrm{L}$ ) in a total volume of $25.5 \mu \mathrm{L}$.

The selective amplification reactions were performed in $10 \mu \mathrm{L}$ solution containing the following: $2.5 \mu \mathrm{L}$ pre-amplified DNA, $0.05 \mu \mathrm{L}$ Platinum Taq DNA polymerase $(5 \mathrm{U} / \mu \mathrm{L}), 1.0 \mu \mathrm{L} 10 \mathrm{X}$ PCR buffer with $\mathrm{Mg}^{2+}, 3.95 \mu \mathrm{L}$ distilled water, $2.25 \mu \mathrm{L}$ Msel primer, and $0.25 \mu \mathrm{L}$ EcoRI primer. PCR was performed in a Techne TC-512 thermocycler for 30 cycles of $94^{\circ} \mathrm{C}$ for $30 \mathrm{~s}, 54^{\circ} \mathrm{C}$ for $30 \mathrm{~s}$, and $72^{\circ} \mathrm{C}$ for $60 \mathrm{~s}$. The sequences of selective primers used to amplify each of the 21 DNA samples are provided in Table 2 . 
Table 2. Sequences for the adapters and selective primers used for the AFLP analysis in DNA samples of Pilosocereus gounellei.

\begin{tabular}{|c|c|}
\hline Adapters/primers & Sequence $\left(5^{\prime}-3^{\prime}\right)$ \\
\hline \multicolumn{2}{|l|}{ Adapters } \\
\hline \multirow{2}{*}{ EcoRI } & 5'-CTCGTAGACTGCGTACC-3' \\
\hline & 3'-CATCTGACGCATGGTTA-5' \\
\hline \multirow[t]{2}{*}{ Msel } & 5'-GACGATGAGTCCTGAG-3' \\
\hline & 3'-TACTCAGGACTCAT-5' \\
\hline \multicolumn{2}{|r|}{ 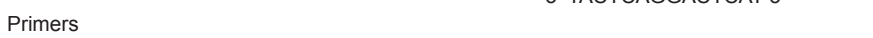 } \\
\hline E-AAG & 5'-GACTGCGTACCAATTCAAG-3' \\
\hline $\mathrm{M}-\mathrm{CTT}$ & 5'-GATGAGTCCTGAGTAACTT-3' \\
\hline E-ACC & 5'-GACTGCGTACCAATCACC-3' \\
\hline M-CAT & 5'-GATGAGTCCTGAGTAACAT-3' \\
\hline E-ACC & 5'-GACTGCGTACCAATCACC-3' \\
\hline M-CAA & 5'-GATGAGTCCTGAGTAACAA-3' \\
\hline E-AGC & 5'-GACTGCGTACCAATTCAGC-3' \\
\hline M-CAG & 5'-GATGAGTCCTGAGTAACAG-3' \\
\hline E-AAC & 5'-GACTGCGTACCAATTCAAC-3' \\
\hline M-CTA & 5'-GATGAGTCCTGAGTAACTA-3' \\
\hline E-ACT & 5'-GACTGCGTACCAATTCACT-3' \\
\hline M-CTA & 5'-GATGAGTCCTGAGTAACTA-3' \\
\hline E-AGG & 5'-GACTGCGTACCAATTCAGG-3' \\
\hline M-CTG & 5'-GATGAGTCCTGAGTAACTG-3' \\
\hline
\end{tabular}

$\mathrm{E}=$ selective primer for $\mathrm{EcoRI} ; \mathrm{M}$ = selective primer for Msel.

Four $\mu \mathrm{L}$ PCR product was added to $3 \mu \mathrm{L}$ denaturation buffer (99\% formamide, $10 \mathrm{mM}$ EDTA, pH 8.0, $1 \mathrm{mg} / \mathrm{mL}$ xylene cyanol, and $1 \mathrm{mg} / \mathrm{mL}$ bromophenol blue), and the samples were heated at $94^{\circ} \mathrm{C}$ for $3 \mathrm{~min}$. After denaturation, the samples were loaded on an $8 \%$ denaturing polyacrylamide gel (Creste et al., 2001). Electrophoresis was performed in a vertical chamber (FBSEQ-3445, Fisher Scientific; Life Technologies do Brasil Ltda, São Paulo) for 3 h 15 min at 65 W in 1 X TBE buffer. After electrophoresis, the gel was fixed with $0.5 \%$ acetic acid and $5 \%$ ethanol for $20 \mathrm{~min}$ and then stained with silver nitrate, according to the protocol of Beidler et al. (1982). After staining, the gel was again fixed using $10 \%$ acetic acid for 20 min and then stored in water.

\section{Data analysis}

All 21 plantlets were scored for the presence or absence of AFLP bands (a score of 1 was assigned for presence and 0 for absence of the homologous band), and the data were fed into a binary data matrix as discrete variables. The NTSYS-pc package (Rohlf, 1989) was used to compare the data from individual plantlets. Polymorphisms among the AFLP markers were analyzed using STRUCTURE software 2.0 (Pritchard and Wen, 2003), which evaluated the level of genetic admixture between the samples from the three Northeastern States. The genotypes were clustered, with the number of clusters $(\mathrm{K})$ ranging from 2 to 8 , and tested using the admixture model with a burn-in period of 5,000 interations followed by 50,000 Markov Chain Monte Carlo (MCMC) interations, considering the presence or absence of AFLP markers (bands) across the samples. The true number of populations $(\mathrm{K})$ is often identified using the maximal value of $\Delta(\mathrm{K})$ returned by the software. The most probable number $(K)$ of subpopulations was identified as described by Evanno et al. (2005). The graphical output display of the STRUCTURE results was taken as input data for STRUCTURE HARVESTER, a web-based software for visualizing the STRUCTURE output and implementing the Evanno method (Earl and von Holdt, 2012) to obtain a graphical representation. 


\section{RESULTS}

The fingerprint pattern of the xiquexique samples showed a high genetic diversity among the samples. The seven primer pairs amplified 703 AFLP markers, of which $700(99.57 \%)$ were polymorphic (Table 3). The percentage of polymorphic fragments ranged from $95.3 \%$ for the primer pair E-AAG x M-CTT to $100 \%$ for E-ACC x M-CAT, E-ACC x M-CAA, E-AGC x M-CAG, E-ACT x M-CTA, E-ACT x M-CTA, and E-AGG x M-CTG pairs. The largest number of informative markers (126) was detected using the primer combination E-AAC $\times$ M-CTA, while the E-AAG $\times$ M-CTT combination revealed the lowest number of polymorphic fragments (48), in the xiquexique samples.

Table 3. Number of fragments obtained with the seven primers combinations and the polymorphisms (PAF) detected in the 21 samples of Pilosocereus gounellei.

\begin{tabular}{lcrr}
\hline Primer combination & Amplified fragments & PAF & $\%$ P \\
\hline E-AAG $\times$ M-CTT & 48 & 46 & $95.3 \%$ \\
E-ACC $\times$ M-CAT & 82 & 82 & $100.0 \%$ \\
E-ACC $\times$ M-CAA & 96 & 96 & $100.0 \%$ \\
E-AGC $\times$ M-CAG & 122 & 122 & $100.0 \%$ \\
E-AAC $\times$ M-CTA & 126 & 125 & $99.2 \%$ \\
E-ACT $\times$ M-CTA & 118 & 118 & $100.0 \%$ \\
E-AGG $\times$ M-CTG & 111 & 111 & $100.0 \%$ \\
Total & 703 & 700 & $99.21 \%$ \\
\hline
\end{tabular}

Percentage of polymorphic fragments ranged from $72.55 \%$ in the PI sample to $82.79 \%$ in the RN sample. In BA samples, the percentage of polymorphic fragments was $70.84 \%$. The values of Nei's identity (I; Nei, 1978) varied from 0.1393 (between the Pi-4 and Cz-18 samples) to 0.7020 (between the Te-1 and Te-2 samples).

The clustering of the 21 xiquexique samples according to a model-based Bayesian algorithm is shown in Figure 2. Each bar in the graph represents a plant and its inferred proportion of AFLP marker admixture. The optimal $\mathrm{K}$ value determined by the Bayesian analysis indicated that the plants were grouped into 4 clusters $(\Delta \mathrm{K} 2=0.00 ; \Delta \mathrm{K} 3=0.1779 ; \Delta \mathrm{K} 4=2.1683 ; \Delta \mathrm{K} 5=1.0511 ; \Delta \mathrm{K} 6=1.0816$; $\Delta \mathrm{K} 7=0.2739 ; \Delta \mathrm{K} 8=0.3873 ; \Delta \mathrm{K} 9=0.0701$; and $\Delta \mathrm{K} 10=0.00)$. The bar plot obtained for the $\mathrm{K}$ value $(\mathrm{K}=4 ; \Delta \mathrm{K}=2.1686)$ and the results were consistent with the evidence of plants with a mixture of DNA fragments of 2, 3, and 4 groups, and plants with fragments predominantly of one of the groups.

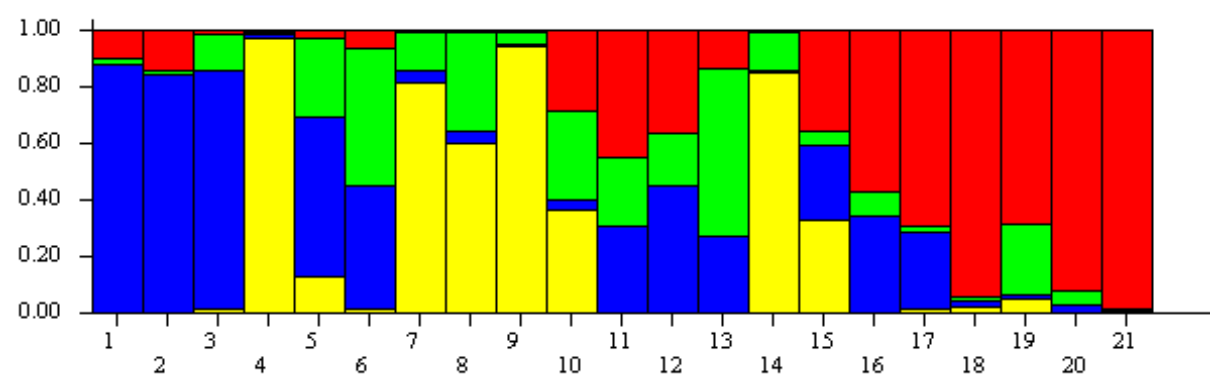

Figure 2. Bar plot-like population structure, based on AFLP markers for plants of Pilosocereus gounellei from Teresina (1-3), Picos (4), Campo Maior (5-6), Queimada Nova (7-11), and Cruzeta (12-21) within the K clusters. Each plant is represented by a single vertical bar broken in $K$ colored segments $(K=4)$, with lengths proportional to each of the $K$ inferred clusters. Each color represents the proportion of fragments for each individual, represented by a vertical bar. 
The bar plot indicates the division of the xiquexique samples, from the three states, according to their genetic relatedness. Table 4 shows that the largest proportion of plants of $P$. gounellei from PI was in the blue group (59.6\%), that of the plants from BA was in the yellow group (54.8\%), and that of the plants from the RN was in the red group (56.2\%). The differential distribution of the highest proportions of plants of each state in different groups $(59.6 \%$ in the blue group, $54.8 \%$ in the yellow group, and $56.2 \%$ in red group) indicates a genetic divergence at the molecular level of these plants.

Table 4. Proportion of plants of Pilosocereus gounellei distributed in each group and number of plants in each state Piaui (PI), Bahia (BA), and Rio Grande do Norte (RN).

\begin{tabular}{lccccc}
\hline State & \multicolumn{3}{c}{ Group } & Number of plants \\
\cline { 2 - 4 } & Red & Green & Blue & Yellow & \\
\hline PI & 0.057 & 0.155 & 0.596 & 0.191 & 6 \\
BA & 0.147 & 0.217 & 0.088 & 0.548 & 5 \\
RN & 0.562 & 0.140 & 0.167 & 0.131 & 10 \\
Mean/total & $\mathbf{0 . 2 5 5}$ & $\mathbf{0 . 1 7 1}$ & $\mathbf{0 . 2 8 4}$ & $\mathbf{0 . 2 9 0}$ & $\mathbf{2 1}$ \\
\hline
\end{tabular}

\section{DISCUSSION}

The polymorphism yielded by AFLP markers in $P$. gounellei was $99.57 \%$, which was significantly higher than that reported previously from research with other cactus species. In a study evaluating the genetic diversity at the DNA level in mandacaru (genus Cereus), six primer pairs were used, to amplify 348 AFLP markers, of which 282 (81\%) were polymorphic (FariaTavares et al., 2013). In the genus Opuntia, AFLP analysis was carried out on one sample each of O. ficus-indica, O. megacantha, O. amyclaea, O. undulate, and O. spinulifera to elucidate genetic relationship amongst species plotted in the first cluster of the cpSSR neighbor joining tree (Nilsen et al., 2005). In this study four primer combinations used to amplify the DNA obtained from the Opuntia samples generated 169 bands of which 131 (77.51\%) were polymorphic. In addition, 86\% of the sites were detected to be polymorphic. The high polymorphism of the amplified fragments of DNA in $P$. gounellei is an important and promising trait to encourage the use of xiquexique in the restoration of degraded areas in Northeastern Brazil and also for proposing genetic improvements in it. The improvement in $P$. gounellei should aim to achieve plants with attributes preferred by humans and animals, such as sweeter fruit, thinner peel, and fewer spines (Almeida et al., 2007).

However, despite the high genetic diversity of AFLP markers in xiquexique, the similarity between plants from the same place was well defined as illustrated in the bar plot (Figure 2). The model-based Bayesian algorithm in the STRUCTURE software is efficient in assigning individuals to their populations of origin (Evanno et al., 2005). Thus, the identification of relatively homogeneous clusters of xiquexique reflecting their origin is evident in the bar plot. The vegetative propagation as the predominant form of multiplication of xiquexique plants may explain the high genetic similarity between plants from the same location and seems to be the cause of the differentiation at molecular level among the plant samples from different regions of the Caatinga biome.

Polymorphism of the amplified fragments of DNA was higher $(82.79 \%)$ in the Cruzeta samples than in the ones from Piauí and Bahia. The genetic variation in samples from Cruzeta as revealed by microsatellite markers was also higher than that in the plantlets from PI and BA (Monteiro et al., 2015). However, due the highest proportion of plants in the red group (56.2\%) should be very important to increase genetic diversity in plants for use in the restoration of degraded 
areas, and also to select samples of contrasting plants for crosses in the breeding program of xiquexique, a wild natural resource important to the livelihoods of local people. The introduction of xiquexique plants with different origins, from other neighboring states that are also part of the Caatinga (Paraíba, Ceará, Maranhão, Pernambuco, Alagoas, and Sergipe), into the experimental field of Cruzeta is needed to promote the natural exchange of genetic material. Such exchanges are required for establishment of biodiversity conservation units and also for broadening of the genetic base of the species.

The AFLP methodology is important to identify genetically homogeneous and contrasting plants, as well as plants sharing DNA markers of different origins. In principle, along with local plants, those sharing genetic material from different origins are ideal source of seeds to produce plants that can restore degraded areas of the Caatinga biome. Restoration of degraded areas in the Caatinga biome is a nationwide concern in Brazil, and for this reason, the biome is included in the National Action Plan for the Conservation of Cactaceae, which is coordinated by the Chico Mendes Institute for Biodiversity Conservation in partnership with international institutions.

\section{ACKNOWLEDGMENTS}

The authors would like to thank CAPES (Coordenação de Aperfeiçoamento de Pessoal de Nível Superior, Brasília, DF, Brasil) for financial support. We would also like to thank Dr. José Geraldo Medeiros da Silva (EMPARN, Parnamirim, RN, Brazil) for the samples provided from the experimental field (Cruzeta, RN).

\section{REFERENCES}

Albuquerque UP and Andrade LHC (2002). Uso de Recursos Vegetais da Caatinga: o caso do agreste do Estado de Pernambuco (Nordeste do Brasil). Interciencia 27: 336-346.

Aljanabi SM, Forget $L$ and Dookun A (1999). An improved and rapid protocol for the isolation of polysaccharide and polyphenolfree sugarcane DNA. Plant Mol. Biol. Rep. 17: 1-8.

Almeida CA, Figueiredo RMF, Queiroz AJM and Oliveira FMN (2007). Características físicas e químicas da polpa de xiquexique. Rev. Cienc. Agron. 38: 440-443.

Andrade AP, Costa RG, Santos EM and Silva DS (2010). Produção animal no semiárido: o desafio de disponibilizar forragem, em quantidade e com qualidade, na estação seca. Rev. Tecnol. Cienc. Agropec. 4: 1-14.

Arif IA, Bakir MA, Khan HA, Al Farhan AH, et al. (2010). A brief review of molecular techniques to assess plant diversity. Int. J. Mol. Sci. 11: 2079-2096.

Barbosa AS, Araujo AP, Canuto TM and Franca VC (2007). Caracterização física e físico-química dos frutos do mandacaru e xique-xique produzidos em região semi-árida do Nordeste Brasileiro. Química Brasil 1: 71-76.

Beidler JL, Hilliard PR and Rill RL (1982). Ultrasensitive staining of nucleic acids with silver. Anal. Biochem. 126: $374-380$.

Byles RS and Rowley GD (1957). Pilosocereus Byl. \& Rowl. nom. gen. nov. (Cactaceae) (Pilocereus K. Schum, non Lem.). Cact. Succ. J. Great Brit. 19: 66-67.

Cavalcanti NB and Resende GM (2007). Efeito de diferentes substratos no desenvolvimento de mandacaru (Cereus jamacaru P.DC.), facheiro (Pilosocereus pachycladus Ritter), xiquexique (Pilosocereus gounellei (A. Webwr ex K. Schum.) Bly. ex Rowl.) e coroa-de-frade. Rev. Caatinga 20: 28-35.

Creste S, Tulmann Neto A and Figueira A (2001). Detection of single sequence repeat polymorphisms in denaturing polyacrylamide sequencing gels by silver staining. Plant Mol. Biol. Rep. 19: 299-306.

Earl DA and Von Holdt BM (2012). STRUCTURE HARVESTER: a website and program for visualizing STRUCTURE output and implementing the Evanno method. Conserv. Genet. Res. 4: 359-361.

Evanno G, Regnaut S and Goudet J (2005). Detecting the number of clusters of individuals using the software structure: a simulation study. Mol. Ecol. 14: 2611-2620.

Faria-Tavares JS, Martin PG, Mangolin CA, Oliveira-Collet SA, et al. (2013). Genetic relationships among accessions of mandacaru (Cereus spp.: Cactaceae) using amplified fragment length polymorphisms (AFLP). Biochem. Syst. Ecol. 48: 12-19. 
García-Zambrano EA, Zavala-García F, Gutiérrez-Diez A, Ojeda-Zacarias MC, et al. (2009). Estimation of the genetic diversity of Opuntia spp. using molecular markers AFLP. Phyton 78: 117-120.

Geornaras I, Kunene NF, Von Holy A and Hastings JW (1999). Amplified fragment length polymorphism fingerprinting of Pseudomonas strains from a poultry processing. Plant Microbiol. 65: 3828-3833.

Knudson L (1946). A new nutrient solution for the germination of orchid seeds. Am. Orch. Soc. Bull. 15: 214- 217.

Labra M, Grassi F, Bardini M, Imazio S, et al. (2003). Genetic relationships in Opuntia Mill. genus (Cactaceae) detected by molecular marker. Plant Sci. 165: 1129-1136.

Lucena CM, Costa GM, Sousa RF, Carvalho TKN, et al. (2012). Conhecimento local sobre cactáceas em comunidades rurais na mesorregião do sertão da Paraíba (Nordeste, Brasil). Biotemas 25: 279-289.

Monteiro ER, Mangolin CA, Neves AF, Orasmo GR, et al. (2015). Genetic diversity and structure of populations in Pilosocereus gounellei (F.A.C.Weber ex K.Schum.) (Cactaceae) in the Caatinga biome as revealed by heterologous microsatellite primers. Biochem. Syst. Ecol. 58: 7-12.

Nei M (1978). Estimation of average heterozygosity and genetic distance from a small number of individuals. Genetics 89: 583-590.

Nilsen LB, Dhillion SS, Camargo-Ricalde SL, Rendón-Aguiar B, et al. (2005). Traditional knowledge and genetic diversity of Opuntia pilifera (Cactaceae) in the tehuacán-cuicatlán Valley, Mexico. Econ. Bot. 59: 366-376.

Oliveira SA, Machado MFPS, Prioli AJ and Mangolin CA (1995). In vitro propagation of Cereus peruvianus Mill. (Cactaceae). In Vitro Cell. Dev. Biol. Plant 31: 47-50.

Pritchard JK and Wen W (2003). Documentation for STRUCTURE software: Version 2. Available at [http://pritch.bsd.uchicago. edu].

Repka RR and Mrácek J (2012). Gymnocalycium esperanzae: A Nothospecies? Haseltonia 18: 105-115.

Resende AG, Mangolin CA and Machado MFPS (2010). Somaclonal variation in Cereus peruvianus Mill. (Cactaceae): its potential to generate new varieties and broaden the species's genetic basis. J. Basic Appl. Genet. 21: 33-42.

Rocha EA and Agra MF (2002). Flora do Pico do Jabre, Paraíba, Brasil: Cactaceae juss. Acta Bot. Bras. 16: 15-21.

Rohlf FJ (1989). NTSYS-pc: Numerical Taxonomy and Multivariate Analysis System. Exeter Publishing Co, New York.

Silva JGM, Silva DS, Ferreira MA, Lima GFC, et al. (2005). Xiquexique (Pilosocereus gounellei (A. Weber ex K. Schum.) Bly. ex Rowl.) em substituição à silagem de sorgo (Sorghum bicolor L. Moench) na alimentação de vacas leiteiras. Rev. Bras. Zoot. 34: 1408-1417.

Silva JGM, Lima GFC, Paz LG, Aguiar EM, et al. (2010a). Utilization of native cacti associated with sorghum silage on cattle feeding. Rev. Elet. Cient. Centauro 1: 1-9.

Silva JGM, Lima GFC, Aguiar EM, Melo AAS, et al. (2010b). Native cacti associated with 'sabiá' and 'flor de seda' shrub hays in male lamb feeding. Rev. Caatinga 23: 123-129.

Silva JGM, Melo AAS, Rego MMT, Lima GFC, et al. (2011). Native cacti associated with 'sabiá' and 'flor de seda' shrub hays in dairly goats'feeding. Rev. Caatinga 24: 158-164.

Vos P, Hogers R, Bleeker R, Reijans M, et al. (1995). AFLP: a new technique for DNA fingerprinting. Nucleic Acids Res. 21: 4407-4414. 